DOI: $10.20472 / E F C .2020 .014 .010$

\title{
LUCIE KUREKOVÁ
}

Faculty of Economics, University of West Bohemia, Pilsen, Czech Republic

\section{PAVLÍNA HEJDUKOVÁ}

Faculty of Economics, University of West Bohemia, Pilsen, Czech Republic

\section{TOMÁŠ HEJDUK}

Research Institute for Soil and Water Conservation, Czech Republic

\section{MIROSLAV CÖLBA}

Water Management Development and Construction Joint Stock Company, Czech Republic

\section{RADEK ROUB}

Faculty of Environmental Sciences, Czech University of Life Sciences, Czech Republic

\section{DRINKING WATER SUPPLY AS A FACTOR FOR DECISIONS TO CHANGE HOUSING - VIEWS OF INHABITANTS IN A NATION-WIDE QUESTIONNAIRE SURVEY}

\begin{abstract}
:
The paper deals with the issue of drinking water supply as a factor for changing housing and presents selected results of the implemented questionnaire survey in the Czech Republic from the perspective of Czech inhabitants over the age of 15. The paper presents the particular outputs of project no. TL02000060 entitled "Availability of Drinking Water for Inhabitants of Small Municipalities as an Indicator of the Socioeconomic Development of Society", which was created with the support of the Technology Agency of the Czech Republic.
\end{abstract}

\section{Keywords:}

Water Supply, Questionnaire, Municipalities, Drinking water, Housing

JEL Classification: Q25, Q31, 018 


\section{Introduction}

Drinking water supply is a significant part of the development of even the smallest communities in terms of their number of inhabitants. This paper is a free continuation of the paper "Drinking Water Supply as Development Potential of Municipalities - Views of Mayors of Small Municipalities in a Nation-wide Questionnaire Survey", but looks at the given issue from a different perspective, i.e. as viewed by the public.

Drinking water supply is a very important topic, even despite many improvements in this area in recent years. For example, as the former director of the Water Supply and Sewerage Association of the Czech Republic (SOVAK ČR) Author Vlasák has stated, the number of citizens with access to water systems has grown from $84 \%$ to $95 \%$ in the last 30 years, which in practice is an increase of roughly one million inhabitants (Naše voda, 2020).

Despite many improvements in the area of drinking water supply in the Czech Republic, however, it is evident that the issue of drinking water is a fundamental global problem. As stated in public opinion research implemented by the Public Opinion Research Centre of the Institute of Sociology at the Czech Academy of Sciences (CVVM) in June 2020, which focused on the environment, inhabitants of the Czech Republic see the most serious global problems to be the accumulation of waste; pollution and lack of drinking water; pollution of the oceans; destruction of rainforests; harmful substances entering into plants and animals; and air pollution. The most pressing global problem appears to be the accumulation of waste and a lack of drinking water, which was labelled "very serious" by more than three fifths of respondents, $65 \%$ for the accumulation of waste and $62 \%$ for the lack of drinking water (CVVM, 2020).

The seriousness of the issue of drinking water supply is supported by other studies and scientific articles. For example, Hejduková and Kureková (2020) focused their study on the perception of global environmental threats in the Czech Republic from 2014 to 2018 and researched which global problems are seen by inhabitants of the Czech Republic to be the most serious (problems with water again ranked highest). The study also analyzed the seriousness of a lack of drinking water among individual regions. Kameníčková (2019) has pointed to the fundamental role of water infrastructure as a developmental potential for municipalities, similarly to Bernard (2011) and others.

People's stances towards and perception of drinking water supply are a very important aspect in decisions about where to live or to change housing. There are many reasons for this argument, and a fundamental one is the fact that high-quality drinking water is a condition for the operation and development of a community (Přinosil, 2005). Thus, from this fact, we can infer interest in living in a location which provides high-quality drinking water.

This paper aims to present the individual results of the completed questionnaire survey and, by doing so, will point to the importance of drinking water supply in small municipalities from the perspective of inhabitants of the Czech Republic and assess the degree to which drinking water supply is a factor for decisions to change housing. 


\section{Data and methodology}

The empiric method of questionnaire survey was chosen for data collection. This survey was implemented via an electronic questionnaire, and data collection took place in the spring of 2020. The target group were inhabitants of the Czech Republic over the age of 15. A total of 1,000 completed questionnaires were gathered from the addressed respondents. Questions focused on finding out what factors influence the choice of the town or city in which the interviewee would like to live. A basic summary of respondents according to selected characteristic attributes is provided in Table 1.

Table 1 shows how the percentage share of respondents differs from the percentage share of the population of the Czech Republic - see the Diff column [CZ-Questionnaire]. Data about the population of the Czech Republic was gathered from the database of the Czech Statistical Office (CZSO). In terms of population distribution according to highest achieved education, unfortunately data was available only for 2011, when the last Population and Housing Census was carried out. Because this is relatively old data from a statistical perspective, it is rather probable that this structure does not correspond to the present distribution of the population. It is also probable that the share of the population with achieved education marked Without Secondary School has also decreased, being replaced by the share of inhabitants with education marked as Secondary School and University Education. The rest of the data from CZSO was acquired in 2019, and thus the presented structure according to selected attributes corresponds to the state of the population. In terms of the comparison of structure by sex, the share of responses from men and women does not differ greatly from the distribution of men and women throughout the whole Czech Republic. A greater share of inhabitants with secondary and university education took part in the survey than is found in the Czech Republic. In the Czech Republic, almost $23.3 \%$ of the population is older than 65 , but this group makes up only $7.5 \%$ of the questionnaire survey; on the other hand, older inhabitants are realistically less likely to make decisions about changing their place of residence. For the other age groups, the share of representation is close to the age structure of the Czech population. Furthermore, the structure of the population and respondents according to the size and region of their present place of residence is relatively close to the structure of respondents gained from the questionnaire survey. The similarity of the structure of acquired data according to selected attributes heightens the predicative ability of the questionnaire survey's results.

Table 1: Basic summary of data on respondents

\begin{tabular}{|c|c|c|c|c|}
\hline \multirow[b]{2}{*}{ Attribute } & \multicolumn{2}{|c|}{ Questionnaire } & \multirow{2}{*}{$\begin{array}{c}\text { Czech Rep. } \\
\% \\
\end{array}$} & \multirow{2}{*}{$\begin{array}{c}\text { Diff } \\
\text { [CZ-Questionnaire }] \\
\text { p. b. }\end{array}$} \\
\hline & Number & $\%$ & & \\
\hline \multicolumn{5}{|l|}{ Sex } \\
\hline Male & 512 & $51.2 \%$ & $49.3 \%$ & -1.9 \\
\hline Female & 488 & $48.8 \%$ & $50.7 \%$ & 1.9 \\
\hline \multicolumn{5}{|l|}{ Education } \\
\hline Without Secondary & 280 & $28.0 \%$ & $53.9 \%$ & 25.9 \\
\hline Secondary with Graduation & 415 & $41.5 \%$ & $28.6 \%$ & -12.9 \\
\hline University & 305 & $30.5 \%$ & $17.5 \%$ & -13.0 \\
\hline
\end{tabular}




\begin{tabular}{|c|c|c|c|c|}
\hline \multirow[b]{2}{*}{ Attribute } & \multicolumn{2}{|c|}{ Questionnaire } & \multirow{2}{*}{$\begin{array}{c}\text { Czech Rep. } \\
\%\end{array}$} & \multirow{2}{*}{$\begin{array}{c}\text { Diff } \\
\text { [CZ-Questionnaire }] \\
\text { p. b. }\end{array}$} \\
\hline & Number & $\%$ & & \\
\hline \multicolumn{5}{|l|}{ Age } \\
\hline $15-24$ years & 181 & $18.1 \%$ & $10.8 \%$ & -7.3 \\
\hline $25-34$ years & 219 & $21.9 \%$ & $15.6 \%$ & -6.3 \\
\hline $35-44$ years & 216 & $21.6 \%$ & $19.3 \%$ & -2.3 \\
\hline $45-54$ years & 161 & $16.1 \%$ & $16.5 \%$ & 0.4 \\
\hline $55-64$ years & 148 & $14.8 \%$ & $14.6 \%$ & -0.2 \\
\hline 65 or older & 75 & $7.5 \%$ & $23.3 \%$ & 15.8 \\
\hline \multicolumn{5}{|l|}{ Size of present place of residence } \\
\hline Up to 499 inhabitants & 63 & $6.3 \%$ & $7.8 \%$ & 1.5 \\
\hline $500-1.999$ inhabitants & 136 & $13.6 \%$ & $19.2 \%$ & 5.6 \\
\hline $2.000-4.999$ inhabitants & 87 & $8.7 \%$ & $12.1 \%$ & 3.4 \\
\hline 5.000-19.999 inhabitants & 182 & $18.2 \%$ & $18.5 \%$ & 0.3 \\
\hline 20.000-99.999 inhabitants & 256 & $25.6 \%$ & $20.2 \%$ & -5.4 \\
\hline 100.000 or more inhabitants & 276 & $27.6 \%$ & $22.2 \%$ & -5.4 \\
\hline \multicolumn{5}{|l|}{ Region of present residence } \\
\hline Capital City of Prague & 136 & $13.6 \%$ & $12.4 \%$ & -1.2 \\
\hline Central Bohemia & 119 & $11.9 \%$ & $13.0 \%$ & 1.1 \\
\hline South Bohemia & 57 & $5.7 \%$ & $6.0 \%$ & 0.3 \\
\hline Pilsen & 50 & $5.0 \%$ & $5.5 \%$ & 0.5 \\
\hline Karlovy Vary & 25 & $2.5 \%$ & $2.8 \%$ & 0.3 \\
\hline Ústi nad Labem & 80 & $8.0 \%$ & $7.7 \%$ & -0.3 \\
\hline Liberec & 39 & $3.9 \%$ & $4.1 \%$ & 0.2 \\
\hline Hradec Králové & 51 & $5.1 \%$ & $5.2 \%$ & 0.1 \\
\hline Pardubice & 51 & $5.1 \%$ & $4.9 \%$ & -0.2 \\
\hline Vysočina & 44 & $4.4 \%$ & $4.8 \%$ & 0.4 \\
\hline South Moravia & 118 & $11.8 \%$ & $11.1 \%$ & -0.7 \\
\hline Olomouc & 59 & $5.9 \%$ & $5.9 \%$ & 0.0 \\
\hline Zlín & 50 & $5.0 \%$ & $5.4 \%$ & 0.4 \\
\hline Moravia-Silesia & 121 & $12.1 \%$ & $11.2 \%$ & -0.9 \\
\hline
\end{tabular}

Source: CZSO (2020) and authors' questionnaire survey

Respondents were asked about selected areas that might have an effect on their selection of a certain town or city they would like to live in. A total of 18 areas (questions) that could have an effect on their decisions were formulated. Respondents qualified the importance of individual factors based on the Likert scale (Extremely important; Important; Neither / nor; Not very Important; Not at all important). A summary of these areas is listed in Table 2.

Table 2: Selected questions on the importance of decisions to change location of housing

\begin{tabular}{llll}
\hline ID & Question & ID & Question \\
\hline \hline Q1 & Condition of infrastructure & Q10 & Availability of quality health-care \\
Q2 & Transport service (to regional or local centers) & Q11 & Danger to soil from erosion or degradation \\
Q3 & Air quality & Q12 & Degree of population decline and ageing \\
Q4 & Burden on infrastructure due to traffic & Q13 & Size of area for the development of housing \\
Q5 & Waste management situation & Q14 & Number of work opportunities in the \\
Q6 & Degree of threat from floods & Q15 & Business conditions in the municipality \\
Q7 & Drinking water supply situation & Q16 & Safety in the community \\
Q8 & Waste-water treatment situation & Q17 & Conditions for culture, sport and club activity \\
Q9 & Civil amenities of the municipality - e.g. shops, & Q18 & Amount of money in the general budget \\
\hline
\end{tabular}

Source: authors' questionnaire survey 
Results gained via questionnaire will serve to gain relevant information linked to the issue of drinking water supply in small municipalities and will specifically be used for the project entitled "Accessibility of Drinking Water for Inhabitants of Small Municipalities as an Indicator of the Socioeconomic Development of Society". In the following section Selected results of questionnaire survey, particular findings from the questionnaire survey are presented; in terms of presented results, emphasis is placed on questions concerning issues of water management (i.e. Q6-Q8).

Based on responses, the degree of importance of individual fields in the decision to change one's place of residence was calculated in values in an interval between -1 and 1 . If the score nears -1 , the given field is considered to be unimportant (Not at all important); if the score nears 1 , the given field is very important from the perspective of respondents (Extremely important). The summary of values of the mean score for individual fields is shown in Figure 1. The mean score for individual fields has a value in an interval between -0.042 and 0.743 . The question Q7: Drinking water supply situation was the most important from the respondents' perspective. From this, we can deduce that problems with drinking water supply and thus draughts are currently seen as very serious. The second most important field is seen to be Q16: Safety in the community. As least important, respondents chose field Q12: Degree of population decline and ageing and the second least important field as Q15: Business conditions in the municipality. For the other two questions dealing with water management (i.e. Q6 and Q8), the importance score is roughly around the mean value 0.5 , i.e. it is considered important by a large number of respondents.

\section{Figure 1: Importance of individual fields for deciding to change place of residence}

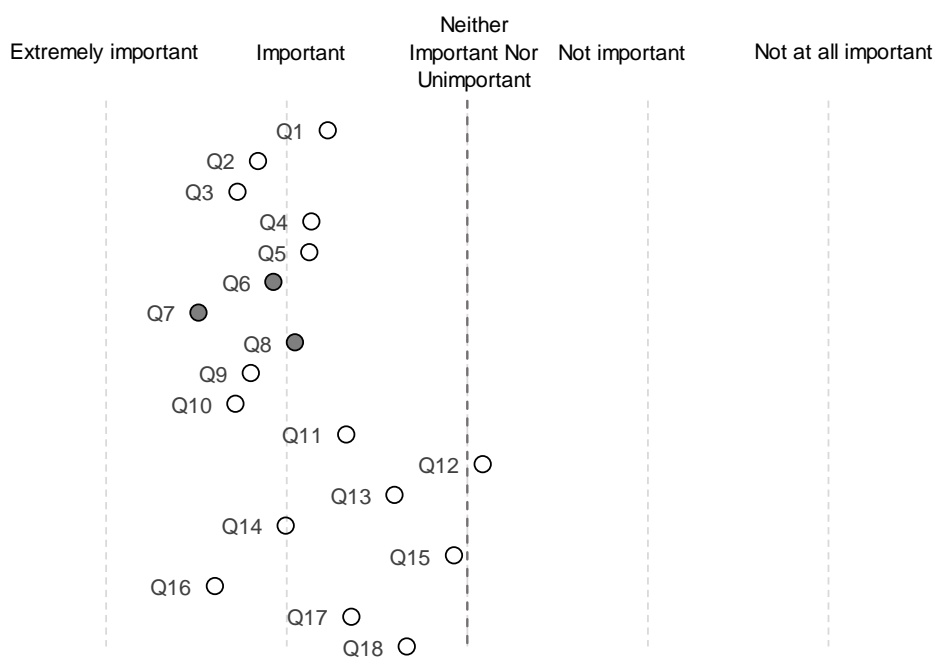

Source: authors' image with data from completed questionnaire survey

\section{Selected results of the questionnaire survey on questions concerning water management}

In the following section of the paper, results for questions Q6-Q8 are described in greater detail. Specifically, responses in regard to sex, age, highest achieved education, place of current residence, and amount of net income are presented. 


\section{Importance of "Degree of threat from floods" (Q6) in deciding to change place of residence}

Figure 2 shows that the balance in decisions about new housing hardly differs between men and women; women only attribute a slightly higher degree of importance to the Degree of threat from floods than men. Differences in decisions are visible among individual age groups - the higher the age, the higher the importance of this question. Results show that respondents with a lower level of education put less emphasis on this field than other respondents with higher education. This finding is also linked to the finding that people with higher net income took a greater interest in the Degree of threat from floods, as it is highly likely that people with a higher level of education also have higher incomes. In terms of the size of the place of residence, only subtle differences can be observed in decision making; in addition, it is clear that inhabitants of the Karlovy Vary region attributed the lowest degree of importance to the Degree of threat from floods in comparison with other regions; on the contrary, this area was the most important for inhabitants of the Hradec Králové region.

\section{Importance of "Drinking water supply situation" (Q7) in deciding on place of residence}

Detailed results for question Q7 are presented in Figure 3. It is evident that women attributed a higher degree of importance to the Drinking water supply situation than men. Differences in decisions are also evident between individual age groups; the higher the age, the higher the level of importance in this field for making decisions. Results show that respondents with the lowest education attributed a greater importance to this field than the other respondents with a higher degree of education. This means that respondents with education labelled "Without secondary school" see the Drinking water supply situation to be more important than the Threat of floods. Furthermore, results show that decisions on Q7 do not differ much depending on amount of net income; however, the group of the population with income between 30 and 40 thousand CZK attribute a greater importance to this issue than the other respondents. In terms of the size of the place of residence, subtle differences in decisions can be seen. However, results show that citizens of the Olomouc Region attributed the least importance to the area of Drinking water supply situation in comparison with populations of other regions; on the contrary, this field was most important to the Moravia-Silesia and Vysočina Regions.

\section{Importance of "Waste-water treatment situation" (Q8) in deciding to change place of residence}

Figure 4 shows that the importance in choosing new housing between men and women hardly differs; men attribute only a slightly higher importance to the Waste-water treatment situation than women. Differences in decision making are then evident between individual age groups. The higher the age, the higher the importance of this question. Results show that respondents with the lowest education most often saw the Waste-water treatment situation to be Extremely important. In terms of amount of income, the importance of this problem was not seen to change according to the amount of net income. In terms of the size of place of residence, we can observe that as the size of place of residence increased, the importance of this area also slightly increased. Furthermore, results showed that inhabitants of the Karlovy Vary Region in comparison with the citizens of other regions attributed the least degree of importance to the Waste-water treatment situation. This field was the most important for inhabitants of the Pardubice Region. 
Figure 2: Importance of the "Degree of threat from floods" (Q6) in deciding to change place of residence
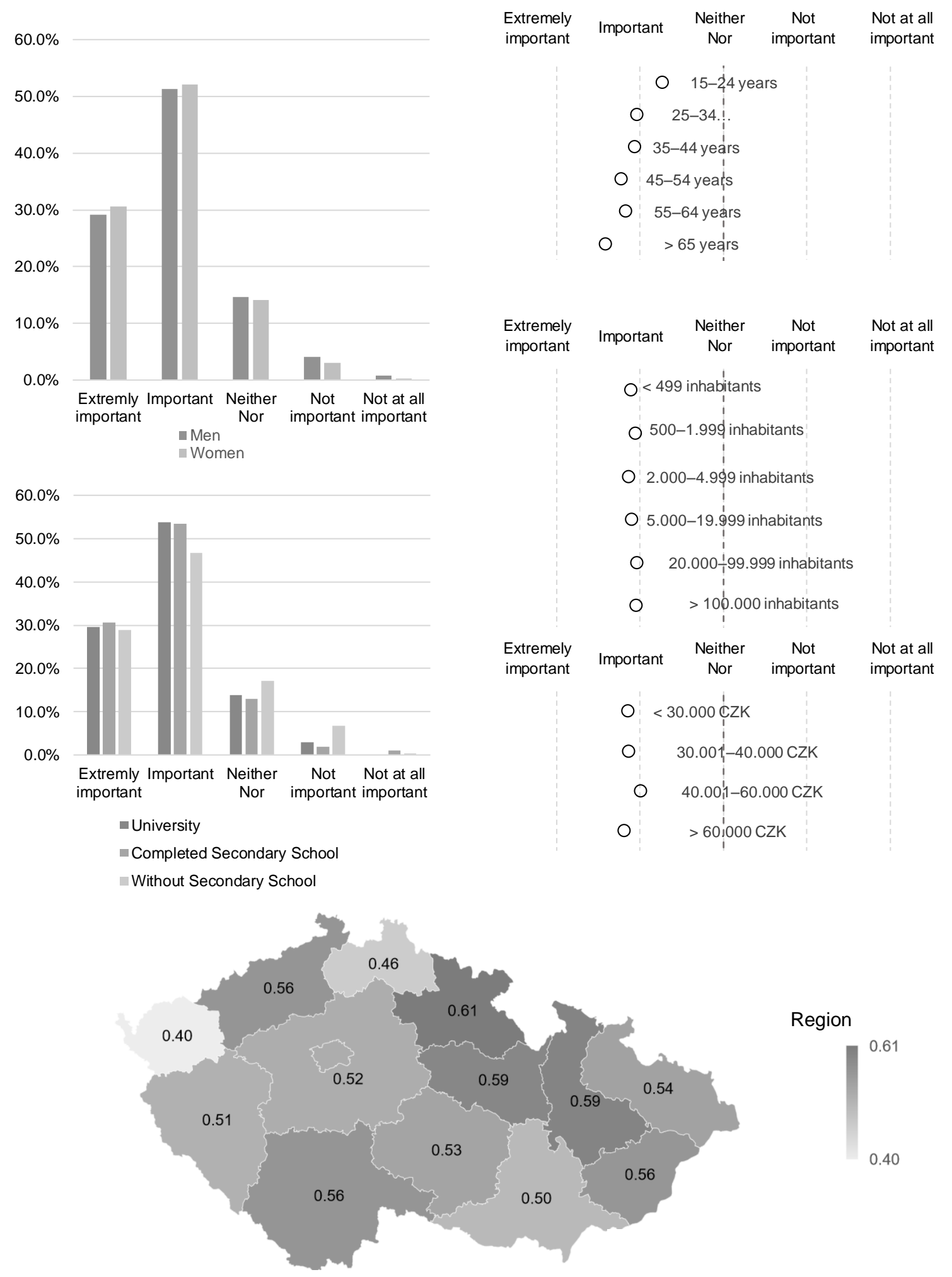

Source: authors' image with data from completed questionnaire survey 
Figure 3: Importance of Drinking water supply situation (Q7) in deciding to change place of residence
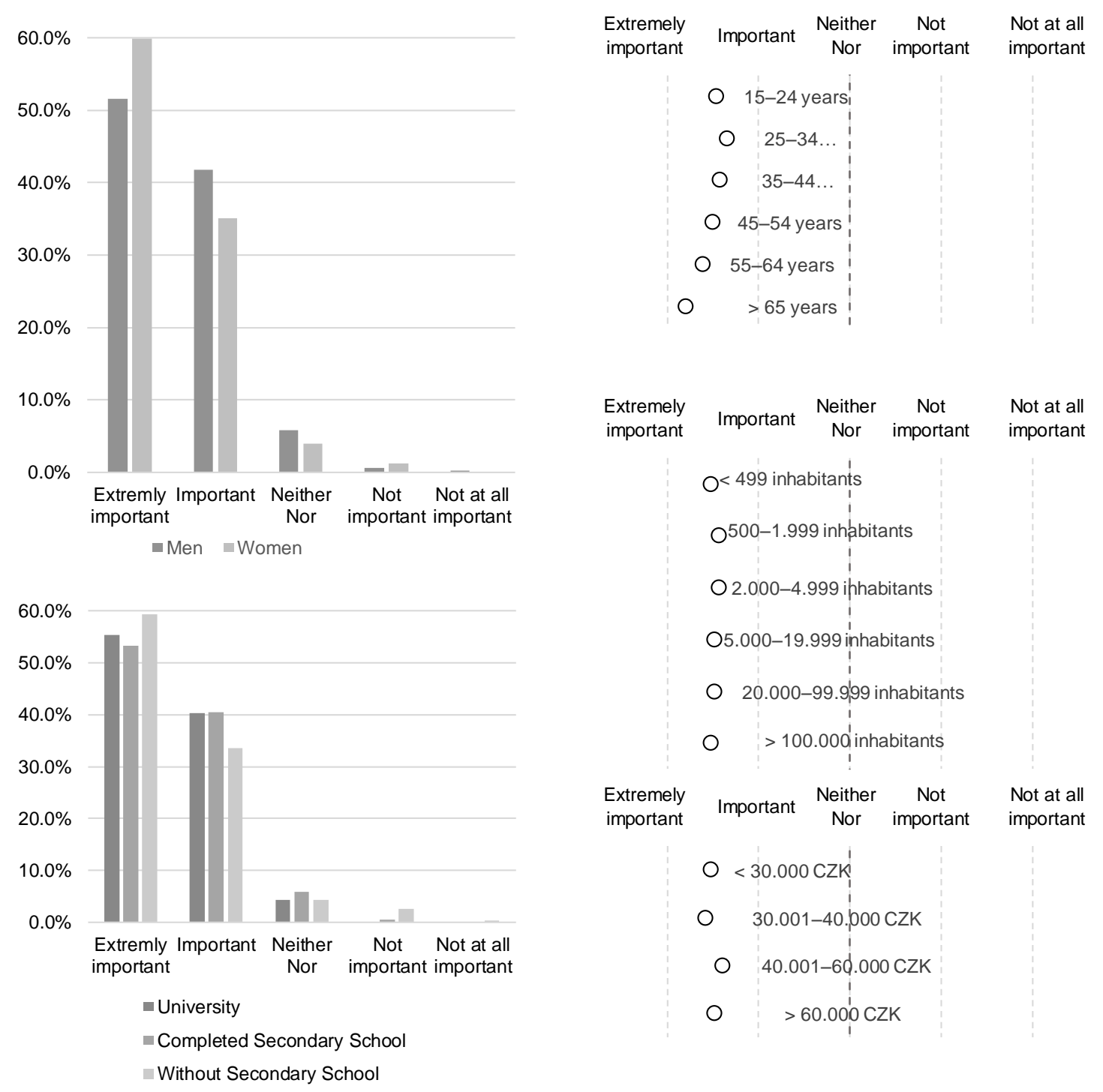
$0<499$ inhabitants
○500-1.999 inhábitants
○ 2.000-4.999 ihhabitants
O5.000-19.999 inhabitants
○ 20.000-99.9/99 inhabitants
○> $>100.000$ inhabitants

$\begin{array}{cccc}\text { Extremely } & \text { Important } & \begin{array}{c}\text { Neither } \\ \text { Nor }\end{array} \text { impot } & \text { Not at all } \\ \text { important } & \text { important }\end{array}$

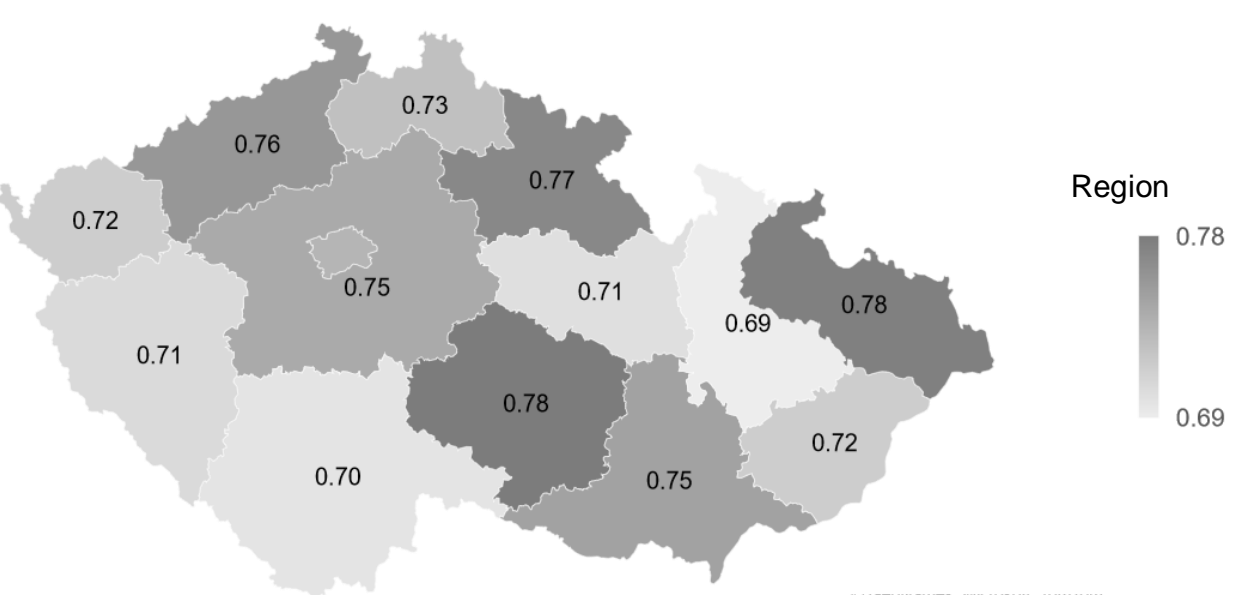

Source: authors' image with data from completed questionnaire survey 
Figure 4: Importance of Waste-water treatment situation (Q8) in deciding to change place of residence
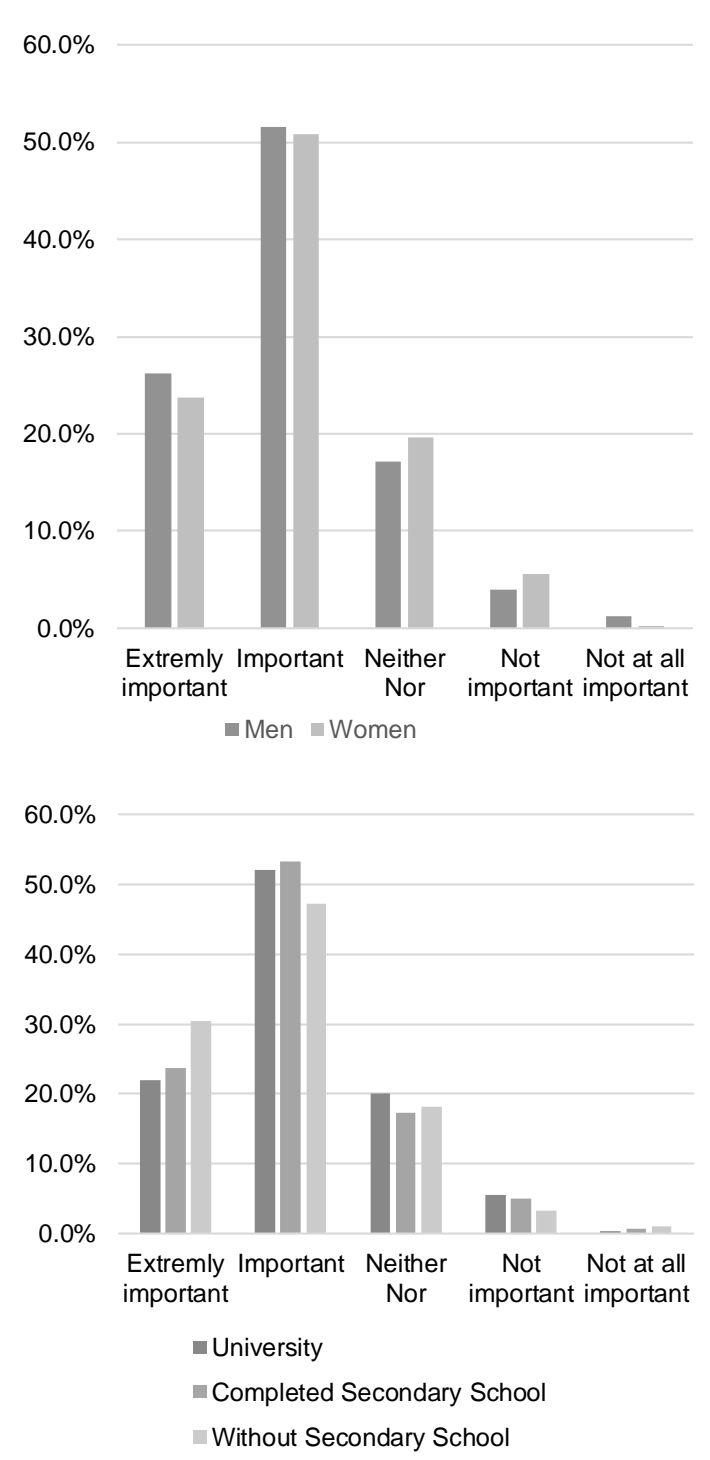

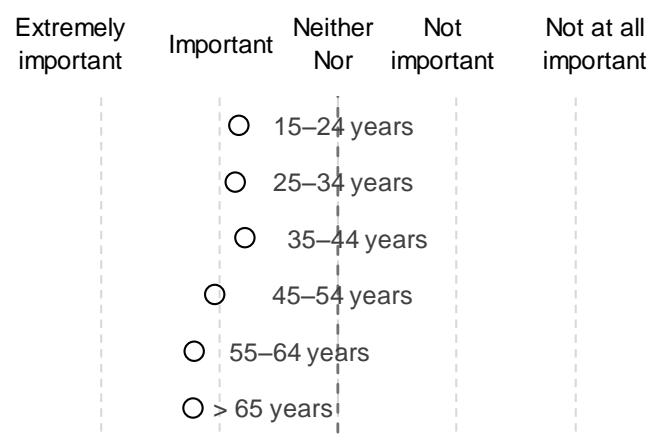

Extremely
important $\begin{array}{ccc}\text { Important } & \begin{array}{c}\text { Neither } \\ \text { Nor important }\end{array} & \text { Not at all } \\ \text { important }\end{array}$ $0<499$ inhabitants

○ 500-1.999 inhabitants O 2.00/0-4.999 inhabitants

○ 5.000-19.999 inhabitants ○ $20.000-99.999$ inhabitants ○> 100.000 inhabitants

Extremely Important Neither Not Not at all important Important Nor important important

$0<30.000$ CZK

○ $30.00_{1} 1-40.000 \mathrm{CZK}$

O 40.0Q1-60.000 CZK

$\mathrm{O} \quad \mathrm{x}_{1} 60.000 \mathrm{CZK}$

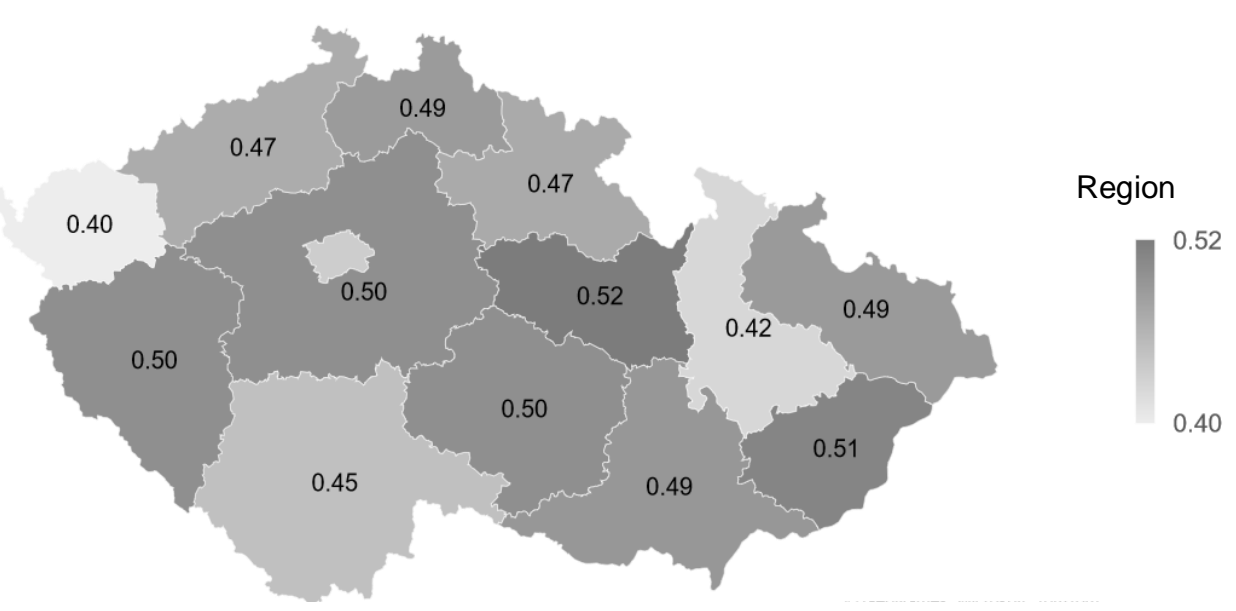

Source: authors' image with data from completed questionnaire survey 


\section{Conclusion}

The goal of the paper has been to present the particular results of the implemented questionnaire survey and by doing so point to the significance of drinking water supply in small municipalities from the perspective of the Czech population and assess the degree to which drinking water supply is a factor for choosing to change place of residence. Data collection was carried out in the form of an electronic questionnaire survey in the spring of 2020. The target group were inhabitants of the Czech Republic over the age of 15, and a total of 1,000 questionnaires were acquired. In regard to selected attributes such as sex, age, education and place of residence, relatively high conformity was reached with the structure of the Czech population, which significantly increases the predicative ability of the questionnaire survey's results.

Based on particular results of the questionnaire survey, we can claim that the most important factor for decisions on a change of place of residence in respondents' minds is the "Drinking water supply situation". From this, we can deduce that the current problem with drinking water supply and thus draughts are considered to be very serious. In terms of the other two questions concerning water management, the importance score was around the mean value of 0.5 , and the given fields are thus seen to be Important by a large number of respondents. In other words, the Degree of threat from floods and the Waste-water management situation plays a significant role in decisions to change housing. It is interesting to note that women placed a higher importance on the Drinking water supply situation than men, and the higher the age, the higher the importance of this field in decision making. Respondents with the lowest achieved education attributed a greater importance to this field than the other respondents with higher education, which means that respondents with education labelled "Without secondary school" see the Drinking water supply situation to be more important than the Threat of floods.

\section{Acknowledgments}

This paper was created with the support of the Technology Agency of the Czech Republic no. TL02000060 entitled "Accessibility of Drinking Water for Inhabitants of Small Municipalities as an Indicator of the Socioeconomic Development of Society."

\section{References}

Bernard, J. (2011). Endogenní rozvojové potenciály malých venkovských obcí - obtížné hledání a měření jejich vlivu. Sociologický časopis / Czech Sociological Review, 47(4), 745-775.

CVVM. (2020). Česká veřejnost o globálních problémech - červen 2020. Tisková zpráva. Dostupné https://cvvm.soc.cas.cz/media/com_form2content/documents/c2/a5251/f9/oe200807.pdf (cit. 28. 8. 2020)

CZSO (2011) Sčitání lidu, domů a bytů. Dostupné z: https://www.czso.cz/csu/czso/scitani-lidudomu-a-bytu; (cit. 31. 7. 2020)

CZSO (2020) Počet obyvatel $v$ obcích České republiky k 1. 1. 2020. Dostupné z: https://www.czso.cz/csu/czso/pocet-obyvatel-v-obcich-k-112019; (cit. 31. 7. 2020) 
Hejduková, P. a Kureková, L. (2020). Water scarcity: regional analyses in the Czech Republic from 2014 to 2018. Oeconomia Copernicana, 11(1), 161-181.

Kameníčková, V. (2019). Obecní rozpočty a výdaje na vodní hospodářství. Deník veřejné správy, rubrika Ekonomika, 1/2019.

Naše voda. (2020). Pro zásobování obyvatel pitnou vodou je zásadní naplněnost přehrad. Naše voda: Informační portal o vodě. Dostupné z: https://www.nase-voda.cz/pro-zasobovaniobyvatel-pitnou-vodou-je-zasadni-naplnenost-prehrad/ (cit. 27. 8. 2020)

Přinosil, M. (2005). Zásobování pitnou vodou v urbanizovaném prostředí. Vědecké spisy Vysokého učení technického v Brně. Edice PhD Thesis. sv. 348. 